\title{
Functioning of the Parliamentary Groups in the Assembly of the Republic of Kosovo 2011-2014
}

\author{
Lavdim Terziu
}

Anton Gojani2

\section{Zemrı Elezi ${ }^{3}$}

\begin{abstract}
1Doctoral student at the South East European University - Tetovo; Email: It19135@seeu.edu.mk 2Doctoral student at the South East European University - Tetovo; Email: antoni.gojani@gmail.com ${ }^{3}$ South East European University, Tetovo, Macedonia; Email: z.elezi@seeu.edu.mk
\end{abstract}

\section{Doi:10.5901/mjss.2016.v7n3s1p36}

\begin{abstract}
The parliamentary groups are formed after free and democratic elections by political parties or various political coalitions under the Rules of Procedure of the Assembly of the Republic of Kosovo. They play an important role by providing a great contribution to the functioning of parliamentary life, representing their voters in the realization of their interests. There are three diversity parliamentary groups, parliamentary groups formed by position, the ones formed by the opposition, and those which do not belong to any party (independent deputies). In democratic systems, members of the parliamentary groups express freely their opinions and interests in order to realize their political programmes. This study aims to reflect the functioning of the parliamentary groups of the Republic of Kosovo during the period 2011-2014. A better functioning of the parliamentary groups would contribute in enhancing the effectiveness of decisions undertaken in the parliamentary sessions on various political issues. The study includes the President of the Assembly of Kosovo, heads of the parliamentary groups, representatives of the parliamentary groups and the person who monitored the Assembly during the last legislation. Among the applied methods used in this study were: qualitative methods and semi-structured interviews; whilst the sourcing techniques (means) used to achieve the interview were: semi-structured questionnaire and a recorder with multimedia tools. Results show that the parliamentary groups in the previous legislation lacked the quality debates, professional assistance, genuine parliamentary democracy, etc. From these results we can conclude that the parliamentary groups of the last legislation did not function at the satisfactory level, and did not use all the legal mechanisms in their strengthening and the independence of their decisions.
\end{abstract}

Keywords: Assembly, parliamentary groups, political parties, heads of parliamentary groups, the President of the Assembly of Kosovo, the plenary sessions.

\section{Introduction}

The parliamentary groups comprise of deputies of political parties, independent deputies, etc., joining at least six deputies to form a parliamentary group.

According to Heidar and Koole (2003) the parliamentary party groups (PPGs), make up the linkage between mass suffrage, parties and parliaments, and are today generally accepted as necessary instruments of parliamentary business.

The role of the parliamentary groups in the Assembly of Kosovo is considered as very important and influential not only in making laws, but also in promoting representative democracy. The fourth legislation of the Assembly of the Republic of Kosovo emerged from the early parliamentary elections on 12 December 2010 and a partial repetition of the election process on 9 and 23 January 2011, due to the irregularities identified by the Central Election Commission. The inaugural session of the fourth legislation of the Assembly was held on 21.02.2011. This paper contains both the theoretical and empirical aspect; on theory it elaborates the legal basis of the formation and functioning of parliamentary groups, the use of literature related to the functioning of the parliamentary groups, and the empirical point of view contains the report by KDI (Kosovo Democratic Institute) after monitoring of the Assembly of Kosovo in the previous legislation, as well as the results of the interviews with key people related to the study.

Although the last parliamentary elections in Kosovo were held in June 2014, our study focuses in $2011-2014$ state legislatures. 


\section{The Value of Democracy}

The word 'democracy' derives from the Greek word "demos" meaning "people" and "kratis" meaning "power". It refers to a political system in which the interests of people prevail. Democratic concept is used with different meanings. In American concept, democracy refers to a political system - a way to get power, while from the standpoint of control, democracy is a system in which ordinary people exercise a high degree of control over their leaders. Democracy does not consist only of the processes and procedures (e.g., rule of the majority, etc.), but it consists of important cultural values, typical for democratic governance. Individualism, equality, and freedom shaped the American idea of democracy. (Denhard \& Denhard (2010). p. 2-3)

From the perspective of representative democracy, the need to study PPGs has only gained importance. Debates on contempt and apathy towards politics and politicians (Politikverdrossenheit in German), in which an alleged 'gap' between voters and representatives, a supposed decline of trust in the political elite, and complaints about partitocrazia figure prominently, have put PPGs in the limelight. (Knut Heidar \& Ruud Koole (2003). p. 2)

\section{The Legal Basis of Forming and Functioning of Parliamentary Groups}

The Constitution of the Republic of Kosovo as the highest legal act in the country, according to the Article 76 defines the internal organization and the method of procedure of the Assembly by applying the Rules of Procedure of the Assembly by two-thirds (2/3) of votes of all deputies, while the Rules of Procedure of the Assembly under Article 20 regulates forming and functioning of the parliamentary groups:

1. Deputies may form a parliamentary group on their political affiliation or program determination.

2. The deputy is entitled to participate equally in a parliamentary group, to withdraw from the group, to form a new group, to join another group or to act as an independent deputy. For each case, the deputy is obliged to notify the President of the Assembly for his/her decision.

3. Establishing a parliamentary group requires 5 percent of deputies of the Assembly or at least six (6) deputies. In cases the number of deputies, members of a parliamentary group goes below this minimum, then the group no longer exists.

4. The new group, formed later, cannot have the same name with another parliamentary group.

5. A deputy may not be a member of more than one parliamentary group.

6. Parliamentary groups are provided with necessary and proportionate space, necessary conditions and equipments, as well as a political staff. The political staff of the parliamentary groups will be remunerated for their performance in accordance with the Decision of the Presidency.

The largest parliamentary group PDK (Democratic Party of Kosovo) of the fifth legislation, after the parliamentary elections of 8 June, led by Xhavit Haliti addressed the Constitutional Court with a request concerning the election of the President of the Assembly of Kosovo of 17 February 2014. They considered that a constitutional violation, not respecting the Article 67 (2) [Election of the President and Vice-Presidents of the Asembly] of the Constitution took place. This Article stipulates that, "The President of the Assembly is proposed by the largest parliamentary group and is elected by the vote of the majority deputies of the Assembly". After the Constitutional Court reviewed the application, it was considered that the decision no. 05-V-001 of 17 July 2014 was unconstitutional, both by the followed procedures, as well as by the content, because it was not the largest parliamentary group who proposed the President of the Assembly, and as a consequence it was invalid. Haliti, Xh. et al. (!7 July 2014). Constitutional Review of the Decision no. 05-V-001, voted by 83 deputies of the Assembly of the Republic of Kosovo on the election of the President of the Assembly of the Republic of Kosovo. Taken from http://www.gjk-ks.org/repository/docs/gjk_ko_119_14_shq.pdf

\section{The Parliamentary Groups in the Assembly of Kosovo from 2010 to 2014}

The parliamentary groups cooperate with the Presidency of the Assembly in the preparation of plenary sessions; they accord to have a common approach in making decisions about the priority issues which need to be addressed in the parliament, they also play a key role in establishing a so-called government, "the coalition government " where the largest parliamentary group gives its proposal to establish a coalition and constitute the government. There are three parliamentary groups, the parliamentary groups formed by the position parties, by the opposition parties as well as those groups that do not belong to any party (independent deputies). (Bajrami A. (2005), Parliamentary Democracy , p. 126127)

An analysis done by the Kosovo Democratic Institute and published by the Forum in January 2015, indicated that 
the parliamentary groups of the last legislation in the Assembly of Kosovo were divided into seven groups: the first parliamentary group comprised of 32 deputies from the Democratic Party of Kosovo (PDK) led by Adem Grabovci, the second parliamentary group comprised of 29 deputies from the Democratic League of Kosovo (LDK) led by Ismet Beqiri, the third parliamentary group comprised of 13 deputies from the Alliance for the Future of Kosovo (AAK) led by Ardian Gjini, the fourth parliamentary group comprised of 13 deputies from the Movement Vetevendosje (VV) led by Visar Ymeri, the fifth parliamentary group comprised of 8 deputies from the Independent Liberal Party (SLS) led by Sasa Rasic, the sixth parliamentary group comprised of 8 members from the Coalition for New Kosovo (AKR) led by Myzejene Selmani, the seventh parliamentary group comprised of 6 deputies from the group 6+ led by Myfera Ainik of KDTP party, and 11 deputies who were not part of any parliamentary groups, one deputy from SDSKIM, three deputies from JSL, two deputies from LB, four of SLS and one deputy from PD. ((Archive of the Republic of Kosovo Assembly)

The Assembly of Kosovo in the fourth legislative period 12.12.2010 - 07.05.2014, consists of 120 seats: 100 seats for all the political subjects directly voted, 10 seats set aside for the representatives of the Serb community, 10 seats set aside for the representatives of other communities: 4 seats for the Roma, Ashkali and Egyptian communities (RAE), 3 seats for the Bosnian community, 2 seats for the Turkish community, 1 seat for the Goran community. (Kuvendi i Republikës së Kosovës (2011). Grupet politike në Kuvendin e Kosovës në periudhën 2010-2014. Taken from http://www.kuvendikosoves.org/?cid=1,107)

\section{Functioning of the Parliamentary Groups}

Regarding legislative observation or structural control, in "Public Administration" of the authors Denhard, R. dhe Denhard, J. (2010), many government programmes (and agencies) first arise in legislative programmes. In response to public requests, executives, the state legislature, city council, or the board of directors approve legislation in order to correct the problem.

How do caucus members deal with the fact of being between a representative of their voters and a member of a political party ? Are they able to fulfil their task based on representative democracy by representing the real will of their voters?

From the series of analyzes done by the Kosovo Democratic Institute on the topic, 'Over 10 years of parliamentarism in Kosovo' published in January 2015, and from the analysis conducted for the parliamentary groups and their operation in the Assembly in the last 12 years, and from the results obtained it appears that parliamentary groups have not been able to make a strong basis to build up a higher representative and legislative institution, as a result of political circumstances and often short-term interests of political parties, the lack of internal party democracy, bad coalitions among political parties, the lack of a culture of parliamentary debate, the unwillingness to provide alternatives for solving problems, etc. Also a great influence on not strengthening the parliamentary groups had the lack of adequate professional assistance in providing advice to deputies who represent their group in parliamentary committees, where for many of the deputies, their first professional work is being a deputy of the Assembly of Kosovo, therefore, you can find him/her sitting in a parliamentary committee without any professional support. Likewise, the functioning of the parliamentary groups represent a problem, because they usually hold their meetings only five or ten minutes before the plenary session takes place, where they get instructions on how to vote, while lacking internal debate. (Kosovo institute democratic (2015) Mbi 10 vjetë parlamentarizëm në Kosovë. p. 29-31)

\section{Data Analysis}

Data analysis were done through interviews, by recording then transcribing and reading them several times. We have highlighted elements that we thought are related to the research question and then analyzed them.

\section{Results}

Interviews regarding the functioning of the parliamentary groups in Kosovo for the period 2011-2014 were not easy to be done, knowing the commitments and positions of respondents. Interviews were conducted with former President of the Parliament of the Republic of Kosovo, heads of parliamentary groups, representatives of political parties and civil society representatives in January and February 2015 in Kosovo, while the qualitative part of the research is based on the achievements of modern societies in the parliamentary field and in the Kosovo experience as the new parliamentary democracy. 


\subsection{Qualitative data}

According to the former President of the Assembly of the Republic of Kosovo of the last legislation Jakup Krasniqi, the parliamentary groups of the opposition parties were in greater numbers, because in the coalition with the position party were the minority groups which have 20 reserved seats, but even though it was a strong opposition, it did not play a great role, because it was not united, and even sometimes a part of the parliamentary group of the opposition supported the government in many decisions, while the most vocal group was the parliamentary group of Vetevendosje. Always, according to him it is the parliamentary groups who make politics in parliament and govern the Assembly; there were several occasions when the opposition parties were united and entailed the position parties to leave the Assembly. This does not happen in other countries. Mr. Krasniqi also said that there were no genuine debates between the parliamentary groups in order for debates to lead in a joint decision making. The reason why the position parties left the parliament, according to him, is because whenever they lost their numbers to take any decision, they left the Assembly, while this does not happen in another country. The weakness of political parties being transferred to the parliamentary groups, then transferred to the institutions is democratic malfunctioning of political parties, parliamentary groups and suffocation of debates, making decisions without any debate, pressuring the deputies to vote a decision out of their will.

According to Adem Grabovci, the parliamentary group of PDK has been operating under the Rules of Procedure of the Assembly conform the legislative and administrative procedures as well as and under the rules of procedure of the group for internal operation; it has also been represented in the Presidency of the Assembly of Kosovo and has taken decisions in accordance with the decision of the Group, and it has cooperated with the Presidency of the Assembly, and with other parliamentary groups of the Assembly on importance issues.

According to the parliamentary group of PDK, there were regular consultation between the deputies of the group, and weekly meetings - at least twice a week. The group has also held regular meetings every Tuesday in order to discuss the agenda of the plenary session which was going to be held every Thursday, or of the extraordinary sessions. The group met also regularly one hour before the plenary session took place, to get to know the course that the sessions will have. The group and the head of the group also had frequent contacts with the heads of parliamentary groups, especially with the Coalition Partner. According to the head of the parliamentary group of AKR, there was a lack of professional assistance especially in legal terms. She says that on one occasion the opposition parties pressured them not to stay in session and there were cases when the parliamentary group of AKR left the session although this proposal was from the parliamentary group of PDK, whose part of the coalition AKR is. According to the representative of the parliamentary group of LDK Salih Morina, the opposition parliamentary groups have greater involvement than the position. He further claims that there was not enough democracy between the parliamentary groups of the opposition and position, and they have not been honest and accurate in their decisions. According to the head of the parliamentary group of AAK of the last legislation Ardian Gjini, the lack of ideological basis made deputies to behave regionally, each one trying to benefit. According to him, politicians are opportunist (trying only to get votes). He says that there must be other ways of gaining votes, without buying it, and our society should reach the stage of being irritated when an elected deputy by them does not vote Kosovo Forces just because of his/her own interest. As long as this logic is absorbed in society, it is very hard to take the politicians out from the opportunism they have. Also, according to him, the deputies lack the achievement of democracy. According to Arbulena Haxhiu, representative of the parliamentary group of $\mathrm{V}$, there was pressure on deputies, not allowing them to exercise their will freely, but asking them to become the machine of the government or of the orders and directives of the government. She further says that there haven't been quality debates on important issues and good parliamentary monitoring by the deputies of the Assembly of Kosovo. There was a lack of legal experts and advisors in order to perform better; there had not been a serious approach towards the drafts, by taking copies without reviewing, then asking once again to review them.

According to the person who monitors the Assembly of Kosovo, Driton Selmanaj from KDI, the parliamentary groups are the view of political parties; yet in Kosovo, a culture of internal democracy is not installed; still the power of the leader is undisputed, therefore, according to him we have only 'leader parties'. He also says that the parliamentary groups most of the time meet 5 minutes before the session begins and there are no debates, they do not engage experts who support the parliamentary groups even though they have a lot of money they receive from the fund of democratization in Kosovo. They do not use this fund for the engagement of experts, therefore, parliamentary groups often do not have clear attitude towards certain issues in the absence of professional expertise. Also according to him, the parliamentary democracy lacks even though the deputy according to the constitution of Kosovo, at the moment he/she takes his/her mandate, he/she is free, independent in the form of thought, action; still he/she is directed by their leader and act upon the decision of the party leader. He further says that there is a lack of professional assistance for the parliamentary groups on all issues, not only for the law, but also for political issues which are discussed there. If these 
two improved through debates within the group and the possibility of having the expertise, parliamentary groups would consolidate and reflect in the democratization of the Assembly. He also says that there is not a clear ideological profile among the parties, therefore political parties suddenly become left-wing and right-wing parties.

\section{Conclusion}

- There is a lack of professional assistance on all matters related to the functioning of the parliamentary groups and the Assembly.

- There is a lack of proper debate within groups where the voice of each deputy should be heard.

- There is a lack of parliamentary democracy as a result of sufficient democracy within the parliamentary groups and the political parties themselves.

- There is a lack of ideological basis to the deputies as a result of non existence of a clear profile of political parties.

- Deputies are being pressured from their leaders to vote according to the request of the leaders and not to their free will which is guaranteed by the Constitution.

- There is a presence of 'Leader Parties' where only one person speaks whereas the others are but voting mechanisms.

- There is a lack of expressing their opinion freely by the deputies on issues that may have different views from the head of the party to which they belong.

- There is a lack of an ideological profile of political parties.

\section{Recommendations}

- There should be professional assistance to all parliamentary groups in all matters by using the budget line dedicated to the parliamentary groups.

- Genuine meetings of parliamentary groups, as well as debates and consultations before the plenary sessions take place should be intensified.

- 'Leader parties' should not exist where only the leader decides whereas the others approve his/her decisions without proper debate within the party.

- Deputies should express their will freely, with no pressure from the others.

- The political parties should have ideological profiles.

\section{References}

Bajrami, A. (2005), Parliamentary democracy, $4^{\text {th }}$ edition, Prishtina: ADEA.

Denhard, R., B \& Denhard, J., V. (2010). Public Administration. Vol 6. Translated from: Blerta Selenica. Tiranë: U.F.O Press

Knut Heidar \& Ruud Koole, Parliamentary Party Groups in European Democracies, Taylor \& Francis e-Library, 2003

Kosovo institute democratic (2015) Over 10 years of parliamentarism in Kosovo. Kosovo: KDI

The Constitution of the Republic of Kosovo.

The regulation of the Assembly of Kosovo

\section{Sources from the Internet}

Haliti, Xh. et al. (!7 July 2014). Constitutional Review of the Decision no. 05-V-001, voted by 83 deputies of the Assembly of the Republic of Kosovo on the election of the President of the Assembly of the Republic of Kosovo. Taken from http://www.gjkks.org/repository/docs/gjk_ko_119_14_shq.pdf (till 9 December 2015)

Assembly of the Republic of Kosovo (2011). Political groups in the Parliament of Kosovo in 2010-2014. Taken from http://www.kuvendi kosoves.org/?cid=1,107 (till 28 December 2014)

\section{Interviews}

With the former President of the Parliament of the Republic of Kosovo of the last legislation, Jakup Krasniqi (09.02.2015).

With the head of the parliamentary group of PDK of the last and current legislation, Adem Grabovci (03.02.2015).

With the head of the parliamentary group of AAK of the last legislation, Ardian Gjini (03.02.2015).

With the head of the parliamentary group of AKR of the last legislation, Myzejene Selmani (21.01.2015). 
With the representative of the parliamentary group of LDK of the last and current legislation, Salih Morina (05.02.2015) With the representative of the parliamentary group of VV of the last and current legislation, Arbulena Haxhiu (02.02.2015). With the person from KDI who monitored the Assembly, Driton Selmanaj (22.01.2015). 